\title{
Analysis of some concepts related to the environment and health with the $\mathrm{N}$-gram method
}

\author{
Ali Çiftçi ${ }^{1}$, Alaaddin Vural $^{2}$, M.Nuri Ural ${ }^{3}$.
}

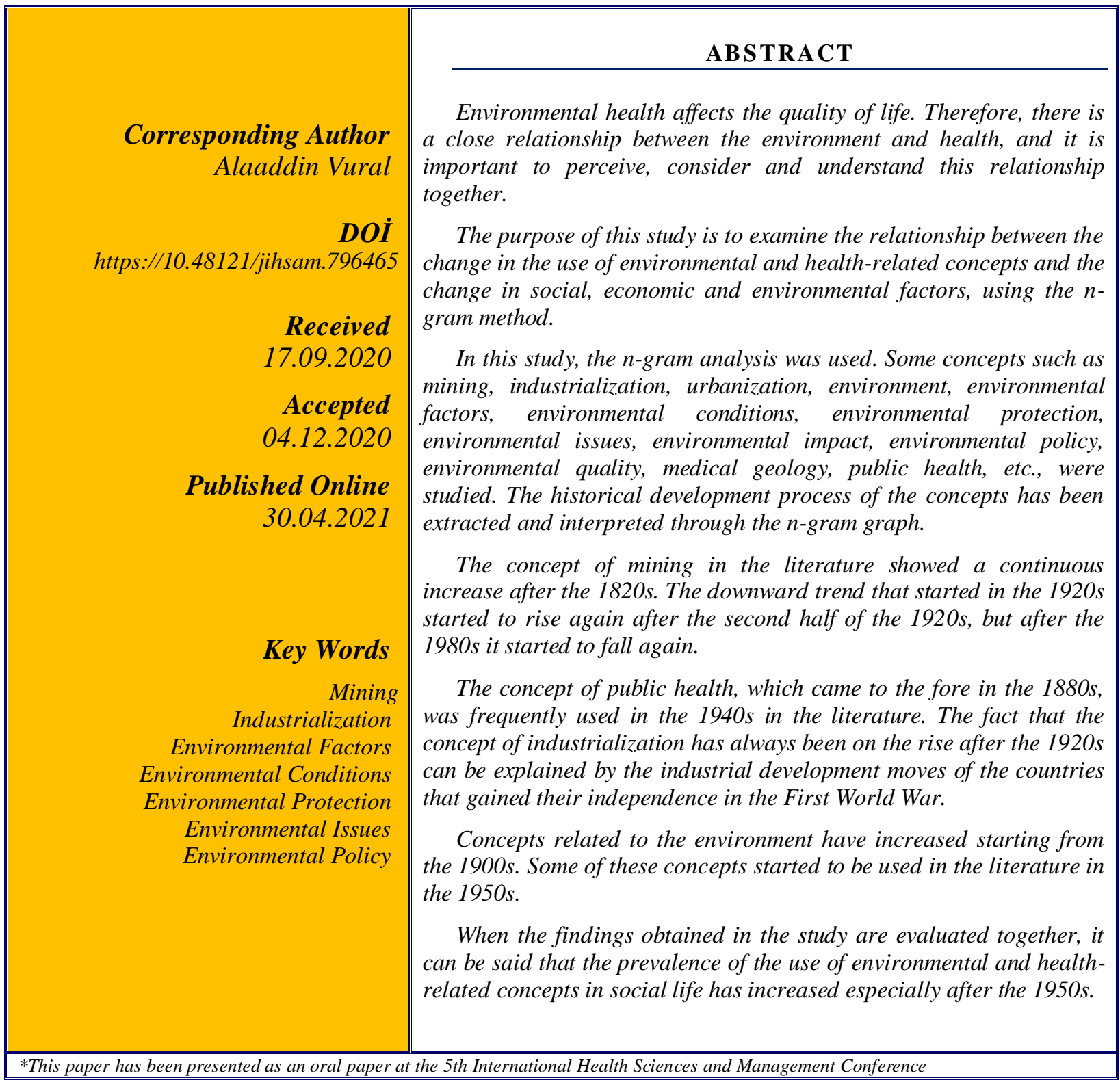

1 Amasya University, Merzifon Faculty of Economics and Administrative Sciences-Department of Political Science and Public Administration, Amasya, Türkiye. ali.ciftci@amasya.edu.tr.hhttps://orcid.org/0000-0002-1273-4867

2 Gümüşhane University, Department of Geological Engineering, Gümüşhane, Türkiye, alaaddinvural@hotmail.com. https://orcid.org/00000002-0446-828X

3 Gümüşhane University, Department of Software Engineering, Gümüşhane, Türkiye, mnu23@yahoo.com. https://orcid.org/0000-0001-7011$401 X$ 


\section{INTRODUCTION}

It has been known for a long time that there is both a direct and indirect relationship between human health and the environment in which they live (Kaya \& Vural, 2020; Vural, 2019, 2018; Vural \& Kaya, 2020; Vural, 2013, 2015a, 2015b). Many concepts and issues related to the environment are closely related to human health. Factors such as water cleanliness, air pollution, mines, sites with mining potential, industrialization and urbanization are important environmental factors and they directly interact with human health (Vural \& Kaya, 2020). The emergence of industrialization has led to the concentration of large population in big cities. Although societies have achieved economic growth by achieving their industrialization goals with mass production, some environmental and social problems have emerged in this process (Tiryakioğlu \& Tuna, 2016). While these reveal the topics of urban issues and problems such as settlement, housing, cleaning, health, transportation, on the other hand, they directly caused environmental and health problems due to the gases released by industrial production, waste materials released to nature, polluted water, destruction of natural habitats. With industrialization, these issues have been brought to the agenda of humanity. Since the beginning of the 20th century, industrialization, environment, and health issues have been discussed together (Rushton, 2003; Sungur et al., 2020).

As a requirement of the digital age, transferring many data to digital media facilitates unlimited access to information and allows very comprehensive analysis of this information. Nowadays, access to information is no longer a problem and methodological development on how to evaluate and analyze so much and comprehensive information in the most efficient way have become important today (Çiftçi, Ural, et al., 2020; Çiftçi et al., 2019; Ural et al., 2019; Ural et al., 2020b; Vural et al., 2020, 2019). Rather than obtaining data, the evaluation of the obtained data, in other words, data mining, has started to take an important place in our lives.
Google, one of the most important digital platform companies and a multinational American joint stock company that makes investments for advertising technologies and search engines, continues to be one of the most important corporate structures of the digital age with the services it provides, as well as being an important web provider and search engine. With its many services, it offers serious infrastructure opportunities for scientific studies today. In this way, it provides a more comprehensive analysis than in the past. It also provides/develops new infrastructure/software services for performing some analyzes. Especially in scientific studies, information sources can be reached easily through Google. Googling has now entered dictionaries as a verb that is used instead of searching the Internet.

$\mathrm{N}$-gram analysis is also one of the useful applications developed by Google and used in Searching/analyzing databases owned by Google (Huang et al., 2012; Reddy \& Pujari, 2006). In the analysis method used with Google infrastructure, it provides the opportunity to do keyword-based research within a large book corpus in the "Google Books" database. In this way, both the numerical and graphical evaluation of the proportional data of the concepts, events and facts planned to be investigated, covering the last 250-300 years, can be provided with this analysis method and the relevant application interface. In this context, the study aims to contribute to the evaluation and correlation of the relationship between environment and health with numerical analysis and examined the interaction and development of related concepts over time.

One of the aims of this study is to make use of the opportunities provided by the digital environment in addressing the relationship between health and environmental issues, and to raise awareness about the opportunities provided by the digital environment in this field in data analysis and data analysis. Another purpose is to examine the time-dependent change of the relationship between environment and health through the findings.

\section{METHOD}

$\mathrm{N}$-gram analysis is an analysis method in which the frequency of repetition of a certain number of subsequences in a character sequence is investigated (Aleahmad et al., 2007; Huang et al., 2012; Reddy \& Pujari, 2006). Although this method is increasingly used in the fields of linguistics, probability, communication theory, natural language processing or computational biology, it helps to determine the frequency of use of malware, which is a fearful element of digital environments, and to develop counter software accordingly. It is used among analysis methods (Aleahmad et al., 2007; Huang et al.,
2012; Reddy \& Pujari, 2006). Recently, N-gram analysis has started to be used in social and political sciences, especially in the research of political, military and economic events and phenomena for the purpose of literature review and in the evaluation of their time-dependent change (Çiftçi et al., 2020; Çiftçi et al., 2019; Çiftçi, et al., 2020; Ural et al., 2019; Ural et al., 2020b, 2020a; Vural et al., 2020, 2019). It is expected that the n-gram analysis conducted within the scope of this study will provide a different perspective on the keywords examined and will inspire more detailed studies using this method. 
Thanks to the awareness to be created, it is estimated that many new studies based on n-gram analysis will be carried out, especially in political/social fields.

\section{FINDINGS AND DISCUSSION}

The study has been divided into three main areas of interest. In the $\mathrm{N}$-gram analysis, the keywords mining, public health, industrialization and urbanization were measured together (Figure 1). Concepts starting with environment are analyzed within themselves (Figure 2). Finally, the n-gram graph was obtained with the concepts of economic development and sustainable development of the mining concept (Figure 3) and the obtained findings were analyzed together.

When the n-gram analysis graph of the keywords in the first group is examined, it is seen that the concept of mining was used in the literature before the $1800 \mathrm{~s}$, but it has increased after the $1820 \mathrm{~s}$, as can be seen in Figure 1. In fact, with the existence of humanity, mining has been a part of human history as a result of people's desire to benefit from the environment. Therefore, this situation in the graphic indicates that it is used in the literature much earlier. However, the frequency of use of the word mining peaked between 1860-1900. This can be explained by the phenomenon of industrialization, which is an important cultural and economic change of humanity. According to traditional historians, the Industrial Revolution started in the second half of the 18th century with James Watt and Richard Arkwright's successive inventions and patents on steam engines, and subsequently affected all Europe, first in Belgium and France, and then the United States (Cardwell, 1972; Van Neuss, 2015). Later, Russia and Japan were affected by this revolution. Towards the end of the 19th century, the industrialization revolution was one of the most important socio-economic transformations that affected the whole world and humanity went through. The peak of the word mining in the 1900s is explained by the increase in mass production in industrialized countries in parallel with the high development of the industry in this period, the increase in energy consumption based on fossil fuel coal and the industrialized countries entering the imperialist sharing war in order to have raw material resources. The use of the concept of mining has a significant co-change with the departure of the world imperial powers towards the First World War, which is a result of this sharing struggle, and the years when the war broke out. In the period of economic depression that the world entered in the years after World War I, the usage frequency of the concept of mining also decreases. The 1930s, which came after the economic crisis, were also the second. It was the years when the world drifted towards the World War, and in these years, the change in the frequency of use of the concept in the literature increases remarkably with the effect of the need for raw materials. After the Second World War, there was a slight decrease in the usage frequency of the concept in the literature as it was after the First World War. The fluctuations observed in the frequency of use of keywords in the literature change in parallel with the social, economic and political events experienced.

When the graphic in Figure 1 is considered in terms of the concept of public health, it is seen that the use of the concept of public health is not as old as the mining concept. This concept started to take place in the literature in the $1860 \mathrm{~s}$ with the rise of industrialization. It is seen that the usage has increased in a rising trend after 1900s. Especially the establishment of non-governmental organizations such as the Public Health Association (1872) and the American Society for Microbiology (1899), which were established in the USA during this period and the publication of the Journal of Infectious Diseases in 1904 contributed to the establishment of the concept in the literature (Levitt et al., 2007, p. 9). In parallel with the establishment of the first public health school within Hopkins University in 1916, it is understood that the concept was used with increasing momentum in the literature in the $1920 \mathrm{~s}$, and saw the peak between 1940-1980. Another of the understandable reasons for this is that infectious epidemics occupied the agenda of humanity at the end of the 1st World War and in the following years. Research on how to combat epidemics has influenced the literature. The influenza epidemic

(https://www.cdc.gov/flu/about/qa/1918flupandemic.h $\underline{\mathrm{tm}})$, which was also called Spanish Flu in 1918-1919 and killed more than 50 million people, the H1N1 Virus and the Hong Kong Flu in the late 1960s are among the most important of these epidemics. Especially in the USA and Europe, the 20th century was the years when vaccination campaigns for various epidemics were very intensely implemented and were successful, and these studies were carried out depending on public health sensitivity (Levitt et al., 2007 , p. 9). Therefore, this has increased the use of the concept in the literature. One of the main elements of the 20th century public health issue is technological changes. In this case, it has been effective in the improvement in the frequency of use of the concept of public health in the literature during the relevant century. After the 1980s, especially the developments in molecular techniques (Levitt et al., 2007, p. 12) are thought to be effective in the re-increase of the concept of public health, whose usage frequency has decreased over time. Although its beginning is controversial, globalization, which is a result of industrialization, and its accelerated industrialization and urbanization have caused effects in the field of health as well as in many other areas (Knobler et al., 2003). The Spanish flu epidemic of 1918 is one of the 
examples to be cited in this sense. The virus was first encountered in ship and train crews, the main engine of globalization, and through these people, the virus spread all over the world. The Covid-19 virus today is the contemporary version of this. When these data are taken together, industrialization and the resulting culture of living together in large populations affect public health on a global scale. Therefore, the concept of combating diseases caused by these factors/public health is used more frequently in the literature. The rise of the concept of mining with the rise in the use of the concept of public health coincides with the recent period, but does not $100 \%$ coincide. This is because the mining activity, which is the main element of industrialization, was first followed by industrialization; and therefore with the increase of public health efforts after the development of globalization with the emergence of the public health problem. When the concepts of industrialization and urbanization are taken into consideration in $\mathrm{N}$-gram analysis, although it is seen that these concepts became widespread in the literature in the early 1900s, concepts such as "Industrial Revolution", "Urban Revolution"; or "Social Revolution" which are widely used for related concepts, it will be seen that they will start from earlier periods. In Figure 1, it is seen that the trends of industrialization and urbanization keywords after the first quarter of the 20th century show parallels with the rise of the concepts of public health and especially mining.

Considering the industrialization and urbanization keywords together, it is seen that the use of these keywords increased in the same period. Their peaks and declines are also in parallel. In the 1920s, both concepts tended to rise, peaked in the mid-1970s, and declined after the 1980s. The parallel use of these two concepts in the literature is a numerical proof based on the literature that industrialization is a development that triggers urbanization. The concept of industrialization differs etymologically from the Industrial Revolution. As it is known, the Industrial Revolution refers to the transition from agricultural economy to industrial economy (Griffin, 2010). The important feature of this period included factors such as technological progress, transition from rural workforce to industrial work, financial investments in new industrial areas. Industrialization, on the other hand, represents the replacement of steam engines by internal combustion engines, the use of electricity much more widely and effectively, the construction of canals, the construction of railways and power lines, and the spread of advanced technological elements, which began to be used in the 20th century. Therefore, industrialization, which is the new version of the Industrial Revolution (Industry1.0, 2.0, 3.0 etc.), finds widespread use with the 1920 s. Urbanization has also started to spread in parallel with industrialization in this context, and Figure 1 also confirms this fact.

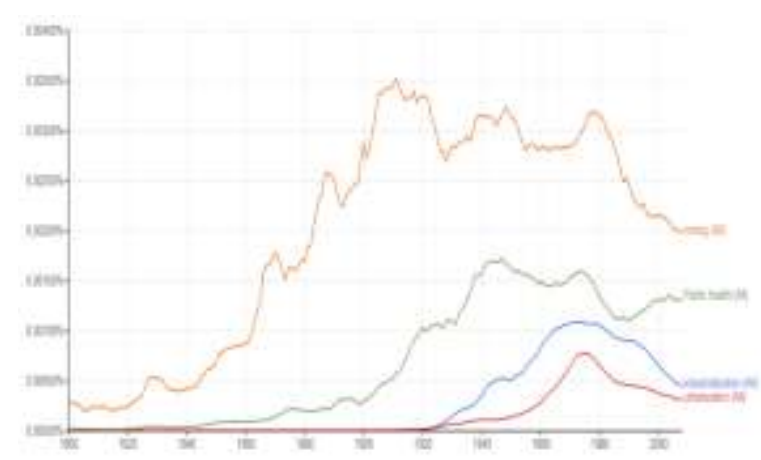

Figure 1. N-Gram Plot of Mining, Public Health, Industrialization and Urbanization Concepts

In the study, many concepts related to the environment were analyzed together, taking into account the relationship between public health and environment. Since the concept of Public Health is discussed in Figure 1, the concept of "Public Health" is not included in Figure 2 in order to avoid confusion. Before moving on to the analysis of the concepts in Figure 2, it should be noted that the following general conclusion that we come across is that the use of the environment and related concepts in the literature started to draw attention in the early 1900s when industrialization increased significantly. In other words, meaningful figures in the graphic emerge at the beginning of 1900 . The graph of the n-gram analysis of the environment and related keywords has been on the rise starting from 1900 in parallel with the development of environmental awareness in the world. The most common environmental concepts in the literature; "Environment", "environmental factors", "environmental conditions", "environmental protection", "environmental issues", "environmental problems", "environmental pollution". All but the last of these were selected as keywords for n-gram analysis and analyzed (Figure 2).

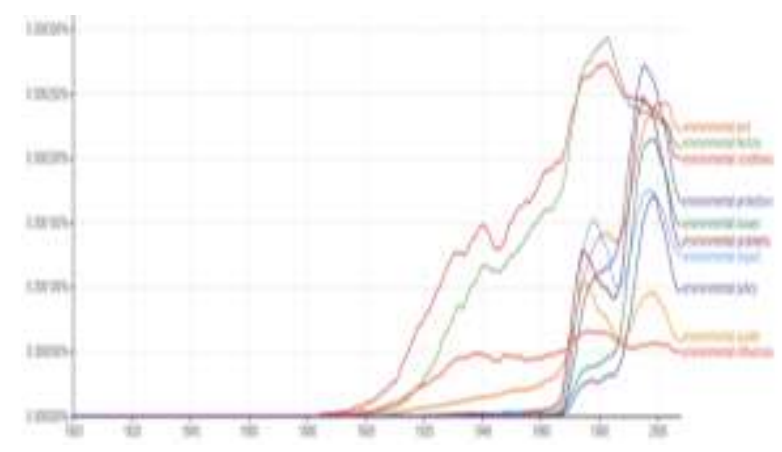

Figure 2. N-Gram Graph of Environment and Keywords Used With It

It should be considered that there is a linear relationship between the handling of the environment and related issues and Industrialization (Figure 1 and Figure 2; note 1920 and beyond). Because the development of industry is a factor that causes environmental problems (Stevenson 2018). The environmental issue is directly related to urbanization. In this case, industrialization and urbanization cause 
environmental problems, which brings sensitivity to the environment. With the emergence of environmental problems, the environment and related books and publications are increasingly taking place in the literature (Figure 2).

When looking at the graph in Figure 2, environmental factors and environmental conditions among the investigated keywords showed a rapid and sharp increase compared to the others. As can be understood, the use of environmental concepts in the literature peaked in the 1980s and 1990s. The 1972 Stockholm Conference on Environment marked the birth of multilateral environmental agreements, but was not effective enough until the mid-1990s. This was the period when states negotiated hundreds of new regional and global agreements, revisions in agreements and new protocols. These included topics such as climate change, biological diversity, marine pollution, marine life, mining, and the trade of hazardous waste (Mitchell, 2002). Especially in the 1990s, the cold war was over, and a unipolar world emerged after years of constant tension. This environment provided a sufficiently optimistic environment for international agreements. During this period, an important article on Foreign Affairs written by Mathews, (1989) in 1989 stated that environmental raw materials (resources) and demographic issues should be taken into the center in defining national security (Mitchell, 2002). In the US elections of 1992 , Bill Clinton devoted the most important part of the presidential election to environmental issues. In the same elections, Bill Clinton's rival, Al Gore, published his book Earth in the Balance, which gained a great reputation especially among US environmentalists and thus increased the number of supporters (Schneider, 1992). Another important event in the 1980s regarding the environment was the successful negotiations of the Vienna Convention and the Montreal Protocol. These negotiations encouraged the international community towards multilateral agreements on environmental issues in the 1980s and 1990s (Stevenson, 2018).

It was brought to the agenda multidimensionally in this period by scientists that the ozone layer in the atmosphere was thinning due to human-induced environmental adversities and therefore our planet went into a serious environmental disaster (Manahan, 2008) and, accordingly, Ozone agreements were successfully realized again in this period with the effect of the mentioned negotiations. When we consider the above data together; Large cities have emerged in industrializing countries since the 1900s. During the 20th century, industrialization, ecology, and environmental issues and concepts in the context of the city were on the agenda. Even, environmental organizations have emerged in many countries, and civil-social and political movements have emerged in this field. All these processes and developments are reflected in the literature. Looking at Figure 2, the increase in the frequency of use of environmental concepts until the 1990s is explained by this. The reason for the decrease in the graph after the 1990s is explained by the adoption of environmental protective regulations in industrialized countries and the necessary measures. Therefore, the frequency of use of relevant keywords in the literature has decreased. It is seen that keywords such as environmental factors, environmental conditions have a greater place in the literature in the graphic. This overlaps with current environmental issues.

In Figure 3, the n-gram graph of the mining concept has been obtained together with the economic development and sustainable development concepts. It is seen that the concept of economic development shows a parallel trend with the concepts of environmental factors and environmental conditions. Seeing the use of the n-gram graph of "economic development" since 1900 is associated with its new entry into the literature.

After the 2nd World War, the sharp increase in the use of the concept of economic development since the mid-1940s is associated with the post-war economic growth moves of the countries. In the graphic, it is seen that the use of the concept of economic development in the literature between the 1950s and 1970s has reached its peak. This is due to the fact that the greatest economic production and growth in Capitalist Industrial societies was experienced in this period. What happened in the economic and social life has been reflected in the literature and the frequency of using the concept of economic development increased and reached its peak in the 1970s. Sustainable development started to be used as a concept after 1970s. The Stockholm Conference held in 1972 gave rise to a focus on environmental problems. The conference also led to a deeper conceptual question of how to reconcile economic development and environmental protection (Stevenson, 2018). UNEP introduced the concept of "eco-development" in the early 1970s, under the leadership of Maurice Strong. At the first meeting of UNEP, Mr. Strong, suggested eco-development as a development style that takes into account the development needs of current generations and that takes into account the natural resource needs of future generations.

With the maturation of many debates, the concept developed well in the meeting held in 1985 with the participation of OECD state ministers, business leaders and environmentalists. OECD's Environment Director, Jim MacNeill, took these matured views on the concept to the Brundtland Commission and proposed the concept of "sustainable development". The concept proposed as eco-development has begun to be accepted as sustainable development (Bernstein, 2000). In June 1992, around 30,000 people from all over the world gathered in Rio de Janeiro / Brazil. These people were environmentalists, activists, journalists, development practitioners, government 
representatives and international organizations. The agenda of these people was our planet. Officially called the UN Conference on Environment and Development (UNCED), the World Summit was the largest conference ever held. This meeting was accepted by framing the concept of sustainable development with all its dimensions. After the concept was widely accepted, it started to be used in many areas related to the environment. In fact, many concepts have found a place in daily life by combining them with the facts and concepts that are also related to development. When Figure 3 is examined, this parallelism can be seen clearly.

In Figure 3, the n-gram graph of the mining concept is obtained together with the concepts of economic development and sustainable development. It is seen that the concept of economic development shows a parallel trend with the concepts of environmental factors and environmental conditions. Seeing the use of the n-gram graph of "economic development" since 1900 is associated with its new entry into the literature.

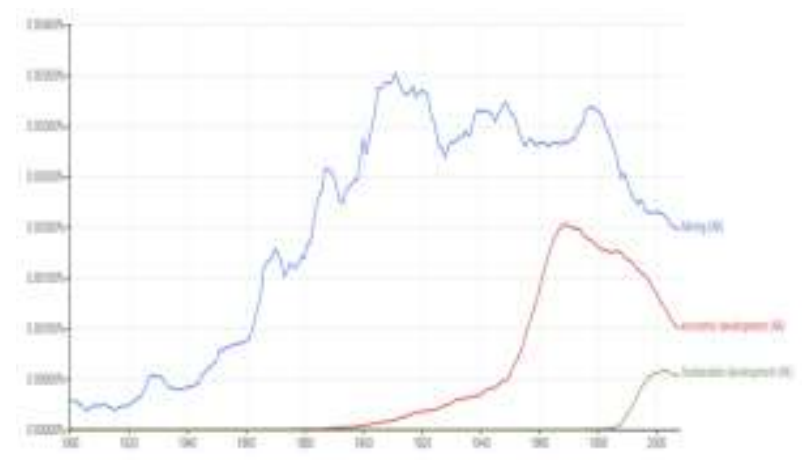

Figure 3. N-Gram Analysis of Mining, Economic Development and Sustainable Development Keywords

\section{CONCLUSIONS}

In this study, the concepts of mining, public health, industrialization and urbanization and the environment and related environmental factors, environmental conditions, environmental protection, environmental issues, environmental problems, economic development, sustainable development concepts are discussed in a way that covers a period of approximately 200 years between 1800-2020. n-gram analysis was performed. As a result of this study;

Although the mining concept dates back to a very old time in human history, it has been observed that the frequency of use in the literature has increased after the 1820s. The frequency of use of the concept in the literature peaked between 1860-1900. The reason for this is explained by Industrialization. The use of the mining concept, which decreased during the economic depression years after the First World War, started to increase again after the 1930s, depending on the increasing need for raw materials in the defense industry. It fell again after World War II.

The concept of public health is a newer concept than the mining concept and entered the literature in the $1860 \mathrm{~s}$. The frequency of use started to increase after 1900s and peaked between 1940-1980. One of the most important reasons for this is that the epidemic diseases seen in the years after the First World War and how to fight them take place in the literature. Today, Covit-19 epidemic disease is experienced as a similar one and keeps the concept of public health on the agenda. Advances in molecular techniques after the 1980s have also been effective in the increase of public health concept.

When the concepts of industrialization and urbanization are examined, it is seen that the increase and decrease in the frequency of use of these two in the literature are parallel. This is because urbanization is a socio-economic phenomenon that develops due to industrialization. The concepts of industrialization and urbanization, which were on the rise in the 1920s, peaked in the mid-1970s and began to decline in the 1980s.

The use of the environment and related concepts in the literature started to attract attention in the early 1900s, when industrialization increased significantly. As is known, industrialization is a factor that causes environmental problems. This is realized both directly through the substances that industrial organizations add to nature and with the effect of urbanization triggered by industrialization that causes environmental problems. Therefore, parallelism is understandable. Environmental awareness in the world has developed since 1900, when industrialization reached a certain level. In parallel with this, the frequency of use of the environment and related concepts in the literature has started to increase starting from 1900. The use of environmental concepts in the literature peaked in the 1980s and 1990s, and tended to decline after this date. The twentieth century has passed in a struggle with the environmental problems caused by industrialization. Numerous civilpolitical initiatives have been effective in this regard.

What draws attention in the analysis of the concept of economic development is that it entered the literature in the 1900s and the frequency of use has been on the rise since the 1920s. After the 1940s, the concept has risen sharply with the effect of post-war economic growth. In the period between 1950 and 1970, when the economic growth of advanced capitalist countries reached the highest rates, the frequency of use of the concept peaked. Tuna \& Ural, (2017) also reached a similar conclusion in their Ngram analysis of basic concepts related to corporate sustainability. The authors associated the decline of economic development after the 2000s with the substitution of the concept with more than one new concept (such as social triple bottom line, corporate social sustainability). 
The concept of sustainable development is a concept that came to the fore in the 1970s. Its use was accepted in the 1990s, after discussions on how industrialization, urbanization and growth can be carried out in a more acceptable way without disturbing the natural balance of the Earth in the 1980s. The frequency of use of the concept of sustainable development, which is a relatively new concept, in the literature peaked in the 2000s.

In the light of these findings;

When the n-gram analysis results for the historical period under consideration were examined, it was found that the use of selected keywords in the literature showed significant parallels in the last 200 years. There are relationships between the frequency of use of mining, public health, urbanization and industrialization concepts in the literature and the frequency of use of the environment and related concepts. It has been observed that the dynamism experienced in the facts and events related to these issues in social and economic life affects the use of concepts related to these in the literature. It is one of the results reached within the scope of the study that
$\mathrm{N}$-gram analysis yields meaningful results in appropriate keywords to be selected. Therefore, it is thought that scanning with n-gram analysis will contribute to the researcher and the research with practical guidance before selecting the appropriate periods for the literature in studies to be conducted on other subjects.

\section{Acknowledgments:}

The study was not supported by any funding. The authors would also like to thank the editor(s) and the anonymous reviewers for their improvement of the manuscript.

\section{Conflict of Interest:}

The authors declare that they have no conflict of interest.

\section{Ethical Approval:}

No Ethics Committee Permission Required

\section{Funding:}

The study was not supported by any funding.

\section{REFERENCES}

Aleahmad, A., Hakimian, P., Mahdikhani, F., \& Oroumchian, F. (2007). N-gram and local context analysis for Persian text retrieval. 2007 9th International Symposium on Signal Processing and Its Applications, ISSPA 2007, Proceedings, 1-4 https://doi.org/10.1109/ISSPA.2007.4555345

Bernstein, S. (2000). 'Ideas, Social Structure and the Compromise of Liberal Environmentalism. European Journal of International Relations, 6(4), 464-512.

Cardwell, D. S. . (1972). Technology, science and history: A short study of the major developments in the history of Western mechanical technology and their relationship with science and other forms of knowledge. Heinemann.

Çiftçi, A. ., Ural, M. N., \& Vural, A. (2020). Baz Metallerin Dünya Siyasi Tarihindeki Önemli Olaylarla Bağlantısının Retrospektif Literatür Taraması Yöntemi ile Araștırılması [Investigation of the Relationship between Base Metal (Pb-Zn-Cu) and Social/Political/Economical Events by N-gram Analysis]. Social Sciences Studies, 5(Nisan).

Çiftçi, A., Ural, M. N., \& Vural, A. (2019). N-gram Analizi ile Baz Metal $(\mathrm{Pb}-\mathrm{Zn}-\mathrm{Cu})$ ve Sosyal/Siyasal Olayların İlişkilendirilebilirliğinin Araştırılması. 4. Uluslararası GAP Sosyal Bilimler Kongresi, 116-124.

Ciftçi, A., Vural, A., \& Ural, M. N. (2020). Analysis of Environmental and Heal Related Concepts with N-Gram Method. 5.Uluslararası Sağlık Bilimleri ve Yönetimi Kongresi, 9-11 Temmuz 2020, Kırşehir/Türkiye.

Griffin, E. (2010). A short History of the British Industrial Revolution. In 1850 over 50 percent of the British lived and worked in cities. Palgrave.

Huang, Y. C., Lin, H., Hsu, Y. L., \& Lin, J. L. (2012). Using ngram analysis to cluster heartbeat signals. BMC Medical Informatics and Decision Making, 12(1). https://doi.org/10.1186/1472-6947-12-64

Kaya, A., \& Vural, A. (2020). Investigation of Natural (226Ra, $232 \mathrm{Th}$ and $40 \mathrm{~K}$ ) and Artificial (137Cs) Radioactivity Concentrations of Kurkpavli and Hazine Mağara Ore Deposits
(Gümüşhane). 5.Uluslararası Sağlı Bilimleri ve Yönetimi Kongresi, 9-11 Temmuz 2020, Kırşehir-Türkiye.

Knobler, S., Mahmoud, A., Lemon, S., \& Pray, L. (2003). The Impact of Globalization on Infectious Disease Emergence and Control: Exploring the Consequences and Opportunities, Workshop Summary - Forum on Microbial Threats. Nap.edu. https://doi.org/doi:10.17226/11588

Levitt, A. M., Drotman, D. P., \& Ostroff, S. (2007). Control of Infectious Diseases: A Twentieth-Century Public Health Achievement. In J. W. Ward \& C. Warren (Eds.), Silent Victories The History and Practice of Public Health In Twentieth Century America. Oxford University Press.

Manahan, S. E. (2008). Fundamentals of Environmental Chemistry. CRC Press.

Mathews, J. (1989). Redefining Security. Foreign Affairs, 68(2), $162-177$.

Mitchell, R. B. (2002). -16. International Environmental Agreements Database Project iea.uoregon.edu/environmentalagreements-date.

Reddy, D. K. S., \& Pujari, A. K. (2006). N-gram analysis for computer virus detection. Journal in Computer Virology, 2(3), 231239. https://doi.org/10.1007/s11416-006-0027-8

Rushton, L. (2003). Health hazards and waste management. British Medical Bulletin, 68(1), 183-197. https://doi.org/10.1093/bmb/ldg034

Schneider, K. (1992). Campaign: Issues - The Environment Clinton and Bush Show Contradictions in Balancing Jobs and Conservation. The New York Times, www.nytimes.com/ 1992/10/13/us/1992-campaign-issues-environment-clinton-bushshow-contradic tions-balancing-jobs.html?pagewant

Stevenson, H. (2018). Global Environmental Politics PROBLEMS, POLICY, AND PRACTICE (Vol. 53, Issue 9). Cambridge University Pres. https://doi.org/10.1017/CBO9781107415324.004

Sungur, A., Vural, A., Gundogdu, A., \& Soylak, M. (2020). Effect of antimonite mineralization area on heavy metal contents and geochemical fractions of agricultural soils in Gümüșhane Province, 
$\begin{array}{llll}\text { Turkey. Catena, 184(January 2019), } 104255 . & \end{array}$ https://doi.org/10.1016/j.catena.2019.104255

Tiryakioğlu, M., \& Tuna, Ö. (2016). Kalkınma Ajanslarının Çevresel Sürdürülebilirliği Sağlamadaki Rolü Üzerine Bir Tartışma. Süleyman Demirel Üniversitesi İktisadi ve İdari Bilimler Fakültesi Dergisi, 21(1), 207-221.

Tuna, Ö., \& Ural, M. N. (2017). N-Gram Analysis of Historic Development of Fundamental Terms Regarding Corporate Sustainability. İşletme Araştırmaları Dergisi-İAD, 9(4), 227-244.

Ural, M.N. Vural, A. Çiftçi, A. (2019). Nadir Toprak Elementlerin Literatürde Kullanım Sıklığının N-Gram Yöntemi ile Analizi ve Kullanım Sıklığı Sosyal/Siyasal Olaylarla Karşılaştırılması. 4. Uluslararası GAP Sosyal Bilimler Kongresi, 135-144.

Ural, M. N., Vural, A., \& Çiftçi, A. (2020a). Conceptual Development Analysis of Health Tourism Based on "N-Gram." 5.Uluslararası Sağlı Bilimleri ve Yönetimi Kongresi, 9-11 Temmuz 2020, Kırşehir/Türkiye.

Ural, M. N., Vural, A., \& Çiftçi, A. (2020b). Nadir Toprak Elementlerinin Sosyo/Kültürel Ekonomik ve Teknolojik Gelişmelerle İlişkisinin N-gram Analiz ile İncelenmesi [Analysis of Rare Earth Elements (REE) in the Literature by Using N-gram Method and Comparison with Social / Political / Economic Even Journal of Social, Humanities and Administrative Sciences, 6(24), 369-379.

Van Neuss, L. (2015). Why Did the Industrial Revolution Start in Britain? SSRN Electronic Journal, January. https://doi.org/http://dx.doi.org/10.2139/ssrn.2696076

Vural, A. (2019). Investigation of the radiation risk to the inhabitants in the region close to the hydrothermal alteration site, Gümüşhane/Turkey. Journal of Engineering Research and Applied Science, 8(2), 1168-1176.
Vural, A. (2018). Assessment of Radiation Exposure Risks of Villagers Living in Sites Close to Hydrothermal Alteration Areas: Demirören, Gümüşhane/NE Turkey. 3rd International Healt Sciences and Management Conference, 298-305.

Vural, A., \& Kaya, A. (2020). Study on the natural and artificial radioactivity risk of the Aktutan alteration site (Gümüşhane). 5.Uluslararası Sağlık Bilimleri ve Yönetimi Kongresi, 9-11 Temmuz 2020, Kırşehir/Türkiye.

Vural, A., Ural, M. N., \& Çiftçi, A. . (2019). N-gram Yöntemi ile Altın-Gümüş Elementlerinin Sosyal/Siyasal Olaylarla İlişkisinin Değerlendirilmesi. 4. Uluslararası GAP Sosyal Bilimler Kongresi, 125-134.

Vural, A., Ural, N., \& Çiftçi, A. (2020). Değerli Metallerin Sosyal / Siyasal / Ekonomik Olaylarla İlişkisinin N- gram Yöntemi İle Değerlendirilmesi [Evaluation of the Relationship between Precious Metals and Social / Political / Economic Events by n-gram Method] Social Mentality and Researcher Thinkers Journal, 6(29), 247-257.

Vural, Alaaddin. (2013). Assessment of Heavy Metal Accumulation in the Roadside Soil and Plants of Robinia pseudoacacia, in Gumushane, Northeastern Turkey. Ekoloji, 10, 1-10. https://doi.org/10.5053/ekoloji.2013.891

Vural, Alaaddin. (2015a). Assessment of metal pollution associated with an alteration area: Old Gümüşhane, NE Black Sea. Environmental Science and Pollution Research, 22(5), 3219-3228. https://doi.org/10.1007/s11356-014-2907-7

Vural, Alaaddin. (2015b). Contamination Assessment of Heavy Metals Associated with an Alteration Area: Demirören Gumushane, NE Turkey. Journal of Geological Society of India, 86(2): 215-222. Doi:10.1007/s12594-015-0301-9

Webpage: https://www.cdc.gov/flu/about/qa/1918flupandemic.htm 